\title{
Relationship between Export Revenue and Gross Domestic Product in Bangladesh: An Econometric Analysis
}

\author{
Sudip Dey \\ Lecturer, Department of Economics, Premier University, Chittagong, BANGLADESH \\ *E-mail for correspondence: sudipdey1899@gmail.com \\ https://doi.org/10.18034/abr.v8i1.2
}

\begin{abstract}
Export revenue is an important issue for Bangladesh. So analysis the relationship between export revenue and gross domestic product (GDP) is very crucial for the policy makers to develop our domestic economy as well as to create a good economic relationship with the global economy. The main object of this article is to investigate the relationship between export revenue and GDP in Bangladesh. To test stationary correlogram test is used. In this study, I used Granger causality and cointegration test to test the long-run relationship between GDP and export revenue in Bangladesh from 1981-2015. I found the maximum lag length for the model by using vector autoregressive (VAR) lag order selection criteria. In the model GDP was dependent variable and three variables (Remittance, Foreign direct investment, Export revenue) were the independent variables. In correlogram test, I have seen all of my variables were non-stationary at level, but after taking first difference, they became stationary. According to Granger causality test, there was bidirectional causality from export revenue to GDP in Bangladesh. Johansen cointegration test investigated that there was a long-run equilibrium relationship between export revenue and GDP but by using vector error correction model (VECM) I have seen there is no statistically significant long-run relationship between export revenue and GDP. Wald test indicated a statistically significant short-run relationship between the two variables.
\end{abstract}

Key words: Export revenue, GDP, VAR, Cointegration, Vector Error Correction Model (VECM)

\section{INTRODUCTION}

Bangladesh is a developing country. Export can play a potential rule for development of Bangladesh. Economic growth is directly related to export. Exports are component of aggregate demand (AD) and rising export will help increase AD and cause higher economic growth. For Bangladesh export can play a significant rule to build up physical capital, reduce unemployment problem, develop productive capacity and help integrate the domestic economy. Readymade garments (RMG) sector is the main source of our export revenue. $75 \%$ of our export revenue comes from this sector. An estimated 4.2 million people are employed in this sector and most the employers are women, half of whom come from villages. By 2013 there were approximately 5000 factories, part of Bangladesh's US\$19 billion a year export-oriented RMG industry has revolutionized the country in terms of its contribution to GDP growth. Bangladesh exports goods and services to UK, USA, Canada, Japan, Australia, NewZealand and Russia etc. Markets are also opening in the Middle East, Latin America and Africa.

\section{LITERATURE REVIEW}

Saaed and Hussain (2015) found that there is unidirectional causality between exports and economic growth in Tunisia. These results provide that growth in Tunisia was propelled by a growth -led import strategy as well as export-led import and imports are the main source of economic growth of Tunisia. Quddus and Saeed (2005) examined if export and GDP are cointegrated by the using Johansen approach; whether export Granger cause GDP growth; whether Granger cause investment. A positive Granger causal relationship running from export to economic growth is suggested by the test results for the long-run period. Hussain (2014) found that there is Granger causality relationship between exports and economic growth in Pakistan. The relationship between exports and economic growth has long been a subject of great interest in the development literature. Javed et al. (2012) proved that export has a positive and significant impact on the economy of Pakistan and the results showed that international trade is an important factor for Pakistani economy. Akter (2015) revealed that the impact 
of export on economic growth is positive but it is negative for import. Ahmed and Uddin (2009) examined that time series analysis indicate exports, imports and remittances cause GDP growth in the short-run but has no long-run impact. The causal nexus unidirectional long-run GDP growth causes short run income growth but this affect is once again unidirectional. By using Johansen's multivariate frame work they found real GDP, real exports, real imports and real remittances were cointegrated for long-run. Sri Lankan economists Thirunavukkarasu and Achchuthan investigated that export and import have positive and significant relationship for each other and they (export, import) also have significant impact on GDP. Ismail etal. (2010) examined a long-run relationship between export and GDP by using Johansen's cointegration test and error correction model was applied to streamline of the variables on economic growth. Rai and Jhala (2015) found a positive relationship between growth rate and exports. Zaheer etal. (2014) indicated that exports and imports have significant relationship economic growth rate. They also suggested that government should move towards more exchange rate liberalization policy for increasing economic growth. In this paper, I want to investigate the relationship between export revenue and GDP in Bangladesh using the time series analysis with different kinds of econometric models.

\section{MetHodology}

We know causality is the foundation of any study to examine an economic relationship. So I started the empirical analysis with Granger causality test to examine if export revenue Granger causes GDP and / or inversely GDP Granger causes export revenue. Correlogram test is used for testing the time series data are stationary or not. For optimal lag length selection, I used Vector Autoregressive (VAR), model. To test the long-run relationship between GDP and export revenue Johansen cointegration test is run. Vector error correction model has used whether the variables have a long-run significant relationship or not. All of the econometric tests are done by Eviews-7 and SPSS-20.

\section{DATA SOURCES}

Time series data are used for the model over the 1981-2015 periods in Bangladesh, which are collected from various primary sources. Data on GDP is taken from World Bank. Data on remittances and export revenue are collected from Bangladesh Economic Review, and data on foreign direct investment (FDI) is taken from Bangladesh Bureau of Statistics.

\section{Model Specification}

To examine the relationship between export revenue and GDP, I have specified following the econometric model where GDP is dependent variable and remittance, FDI and export revenue are independent variables. The model is stated as follows:
$G D P=f($ Remittance, FDI, Export revenue)

$G D P_{t}=\alpha+\beta \operatorname{Re} m_{t}+\delta F D I_{t}+\sigma E x r_{t}+U_{t}$

Where, GDP = Gross Domestic Product, Rem = Remittances, FDI = Foreign Direct Investment, Exr = Export revenue. All the variables are counted in Million $\$ \mathrm{US}, \alpha, \beta, \delta, \sigma=$ parameters to be estimate, $\mathrm{U}=$ Stochastic term, and $t=1,2,3, \ldots \ldots . ., 35$ (time period from 1981-2015).

\section{RESULTS AND DISCUSSION}

\section{Correlogram Test}

Correlogram test is used to check the variables are stationary or not. The results have shown that all the variables are non-stationary at level. But when these variables are tested at first difference, then the null hypothesis is accepted, and the alternative hypothesis is rejected. Because all variables' p-values $>0.05(5 \%)$. That means all variables are stationary at first difference and their integrated order is one or I (1).

\section{Optimal Lag Length Selection}

After the correlogram test, I got the maximum lag length by running vector autoregressive (VAR) lag order selection. From table 1 the maximum lag length is 3,' and it is chosen on different criterions' minimum value. All criteria are asking to take 3lag. So my optimum lag would be 3,' and I will use it in Johansen cointegration test and vector error correction model.

\section{Table 1: VAR Lag Order Selection Criteria}

Endogenous variables: GDP REM FDI EXR

Exogenous variables: C; Date: 01/05/17 Time: 7:37

Sample: 135 ; included observations: 32

\begin{tabular}{|c|c|c|c|c|c|c|}
\hline Lag & LogL & LR & FPE & AIC & SC & HQ \\
\hline 0 & -1159.305 & NA & $4.43 \mathrm{e}+26$ & 72.70658 & 72.88979 & 72.76731 \\
\hline 1 & -1049.686 & 184.9827 & $1.29 \mathrm{e}+24$ & 66.85537 & 67.77145 & 67.15902 \\
\hline 2 & -1017.410 & 46.39651 & $4.90 \mathrm{e}+23$ & 65.83813 & 67.48708 & 66.38471 \\
\hline 3 & -948.0863 & $82.32190^{*}$ & $2.01 \mathrm{e}+22^{*}$ & $62.50539 *$ & $64.88721^{*}$ & $63.29490^{*}$ \\
\hline
\end{tabular}

* indicates lag order selected by the criterion

LR: sequential modified LR test statistic (each test at $5 \%$ level)

FPE: Final prediction error

AIC: Akaike information criterion

SC: Schwarz information criterion

HQ: Hannan-Quinn information criterion

\section{Granger causality test}

First I used Granger causality test to examine the relationship between GDP and export revenue for Bangladesh from 1981to 2015. It is a technique to consider both lagged and endogenous relationship. The results of causality between GDP, Rem, FDI, and Exr are contained in table 2. The results show a bidirectional relationship between GDP and Export revenue in Bangladesh. The results of the test are given in the table 2 . 
Table 2: Pair wise Granger Causality Tests

Date: 01/05/17 Time: 11:58

Sample: 135; Lags: 3

\begin{tabular}{|c|c|c|c|}
\hline . & Obs & F-Statistic & Prob. \\
\hline $\mathrm{D}$ (REN & 31 & & 0.2949 \\
\hline \multicolumn{2}{|l|}{$\mathrm{D}(\mathrm{GDP})$ does not Granger Cause $\mathrm{D}(\mathrm{REM})$} & & 8.E-06 \\
\hline 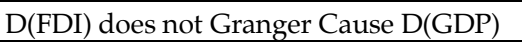 & 31 & & 0.2175 \\
\hline \multicolumn{2}{|l|}{$\mathrm{D}(\mathrm{GDP})$ does not Granger Cause D(FDI) } & & 0.0004 \\
\hline 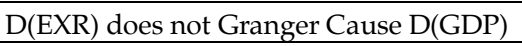 & 31 & & 3.E-09 \\
\hline \multicolumn{2}{|l|}{$\mathrm{D}(\mathrm{GDP})$ does not Granger Cause $\mathrm{D}(\mathrm{EXR})$} & 660 & 8.E-08 \\
\hline 21 & 31 & & 0.0156 \\
\hline \multicolumn{2}{|l|}{$\mathrm{D}(\mathrm{REM})$ does not Granger Cause D(FDI) } & 888 & 0.0053 \\
\hline & 31 & & \\
\hline \multicolumn{2}{|l|}{$\mathrm{D}(\mathrm{REM})$ does not } & 78 & 0.0028 \\
\hline EA & 31 & & 0.004 \\
\hline \multicolumn{2}{|l|}{$\mathrm{D}(\mathrm{FDI})$ does not Granger Cause $\mathrm{D}(\mathrm{EXR}$} & 19.8485 & 1.E-06 \\
\hline
\end{tabular}

\section{Johansen Test of Cointegration}

The precondition for Johansen cointegration test is, the variables must be non-stationary at level but when we convert all the variables into the first difference, and then they will become stationary. Only then we can run the Johansen cointegration test. Here all of my variables are stationary at first difference, and we can run the cointegration test. Table 3 shows the presence of cointegration for the variables adopted in this study, where it is statistically valid. This implies that there is a long-run relationship amongst GDP, remittance, FDI and export revenue. Max Eigenvalue test indicates 1 cointegrating equation at the 0.05 level. Trace indicates 1 cointegrating equation at the 0.05 level. * denotes rejection of the hypothesis at the 0.05 level. The results of the Trace tests indicate the presence that the two variables are cointegrated vectors.

Table 3: Unrestricted Cointegration Rank Test (Trace)

Date: 12/30/16 Time: 04:56

Sample (adjusted): 535

Included observations: 31 after adjustments

Trend assumption: Linear deterministic trend

Series: GDP REM FDI EXR

Lags interval (in first differences): 1 to 3

\begin{tabular}{|c|c|c|c|c|c|}
\hline Hypothesized & & Trace & \multicolumn{2}{|c|}{0.05} & \\
\hline No. of CE(s) & Eigenvalue & Statistic & \multicolumn{2}{|c|}{ Critical Value } & Prob.** \\
\hline None* & 0.953238 & 118.9662 & \multicolumn{2}{|c|}{47.85613} & 0.0000 \\
\hline At most 1 & 0.433196 & 24.02277 & \multicolumn{2}{|c|}{29.79707} & 0.1995 \\
\hline At most 2 & 0.153862 & 6.422759 & \multicolumn{2}{|c|}{15.49471} & 0.6455 \\
\hline At most 3 & 0.039319 & 1.243513 & \multicolumn{2}{|c|}{3.841466} & 0.2648 \\
\hline \multicolumn{6}{|c|}{ Trace test indicates 1 cointegrating eqn(s) at the 0.05 level } \\
\hline \multicolumn{6}{|c|}{ * denotes rejection of the hypothesis at the 0.05 level } \\
\hline \multicolumn{6}{|c|}{${ }^{* *}$ MacKinnon-Haug-Michelis (1999) p-values } \\
\hline \multicolumn{6}{|c|}{ Unrestricted Cointegration Rank Test (Maximum Eigenvalue) } \\
\hline Hypothesized & & Max-Eigen & 0.05 & & \\
\hline No. of CE(s) & Eigenvalue & Statistic & $\begin{array}{l}\text { Critical } \\
\text { Value }\end{array}$ & & $a b .^{* *}$ \\
\hline
\end{tabular}

\begin{tabular}{|c|c|c|c|c|}
\hline None * & 0.953238 & 94.94344 & 27.58434 & 0.0000 \\
\hline At most 1 & 0.433196 & 17.60001 & 21.13162 & 0.1455 \\
\hline At most 2 & 0.153862 & 5.179246 & 14.26460 & 0.7190 \\
\hline At most 3 & 0.039319 & 1.243513 & 3.841466 & 0.2648 \\
\hline Max-eigenvalue test indicates 1 cointegrating eqn(s) at the 0.05 level \\
*denotes rejection of the hypothesis at the 0.05 level \\
"*MacKinnon-Haug-Michelis (1999) p-values \\
\hline
\end{tabular}

\section{Vector Error Correction Model}

Since four variables are cointegrated, I can run VECM model. In the previous test, I have seen that the variables are cointegrated and there is a long-run relationship among the variables. So, in this case, I can run VECM. In this paper I used a multivariate framework, which is given below:

$$
\begin{aligned}
& \Delta G D P_{t}=\alpha_{10}+\alpha_{G D P} \hat{e}_{t-1}+\sum_{i=1}^{m} \alpha_{11}(i) \Delta G D P_{t-i}+\sum_{i=1}^{m} \alpha_{12}(i) \Delta \operatorname{Re} m_{t-i}+\sum_{i=1}^{m} \alpha_{13}(i) \Delta F D I_{t-i} \\
& +\sum_{i=1}^{m} \alpha_{14}(i) \Delta E x r_{t-i}+\varepsilon_{(G D P) t} \ldots \ldots \ldots \ldots \ldots \ldots \ldots \ldots \ldots \ldots \ldots \ldots \ldots \ldots \ldots \ldots
\end{aligned}
$$

\begin{tabular}{|c|c|c|c|c|}
\hline \multicolumn{5}{|c|}{ Method: Least Squares } \\
\hline \multicolumn{5}{|c|}{ Date: $12 / 30 / 16$ Time: 04:59 } \\
\hline \multicolumn{5}{|c|}{ Sample (adjusted): 535} \\
\hline \multicolumn{5}{|c|}{ Included observations: 31 after adjustments } \\
\hline \multirow{6}{*}{\multicolumn{5}{|c|}{$\begin{array}{l}\mathrm{D}(\mathrm{GDP})=\mathrm{C}(1)^{*}\left(\mathrm{GDP}(-1)-26.5640629593^{*} \mathrm{REM}(-1)+\right. \\
\left.229.12319484^{*} \mathrm{FDI}(-1)-4.70907382612^{*} \mathrm{EXR}(-1)+2237.39742401\right)+ \\
\mathrm{C}(2)^{*} \mathrm{D}(\mathrm{GDP}(-1))+\mathrm{C}(3)^{*} \mathrm{D}(\mathrm{GDP}(-2))+\mathrm{C}(4)^{*} \mathrm{D}(\mathrm{GDP}(-3))+ \\
\mathrm{C}(5)^{*} \mathrm{D}(\mathrm{REM}(-1))+\mathrm{C}(6)^{*} \mathrm{D}(\mathrm{REM}(-2))+\mathrm{C}(7)^{*} \mathrm{D}(\mathrm{REM}(-3))+ \\
\mathrm{C}(8)^{*} \mathrm{D}(\mathrm{FDI}(-1))+\mathrm{C}(9)^{*} \mathrm{D}(\mathrm{FDI}(-2))+\mathrm{C}(10)^{*} \mathrm{D}(\mathrm{FDI}(-3))+ \\
\mathrm{C}(11)^{*} \mathrm{D}(\mathrm{EXR}(-1))+\mathrm{C}(12)^{*} \mathrm{D}(\operatorname{EXR}(-2))+\mathrm{C}(13){ }^{*} \mathrm{D}(\mathrm{EXR}(-3))+\mathrm{C}(14)\end{array}$}} \\
\hline & & & & \\
\hline & & & & \\
\hline & & & & \\
\hline & & & & \\
\hline & & & & \\
\hline & Coefficient & Std. Error & t-Statistic & Prob. \\
\hline$C(1)$ & -0.022020 & 0.116494 & -0.189026 & \\
\hline$C(2)$ & 0.144955 & 0.194823 & 0.744033 & 0.4670 \\
\hline$C(3)$ & 0.067075 & 0.226821 & 0.295719 & 0.7710 \\
\hline $\mathrm{C}(4)$ & 0.046506 & 0.588714 & 0.078996 & 0.9380 \\
\hline $\mathrm{C}(5)$ & -4.582433 & 4.269568 & -1.073278 & 0.2981 \\
\hline$C(6)$ & -4.023298 & 4.945088 & -0.813595 & 0.4271 \\
\hline $\mathrm{C}(7)$ & -0.416980 & 4.623882 & -0.090180 & 0.9292 \\
\hline $\mathrm{C}(8)$ & 0.746194 & 24.52954 & 0.030420 & 0.9761 \\
\hline$C(9)$ & 0.862665 & 16.92070 & 0.050983 & 0.9599 \\
\hline$C(10)$ & -15.02848 & 17.49347 & -0.859091 & 0.4022 \\
\hline$C(11)$ & 1.408499 & 2.245559 & 0.627238 & 0.5388 \\
\hline $\mathrm{C}(12)$ & -0.400249 & 1.750651 & -0.228629 & 0.8219 \\
\hline $\mathrm{C}(13)$ & 10.42977 & 2.043848 & 5.103004 & 0.0001 \\
\hline $\mathrm{C}(14)$ & -660.5104 & 1303.875 & -0.506575 & 0.6190 \\
\hline R-squared & 0.938037 & Mean depe & endent var & 5536.903 \\
\hline Adjusted R-squared & 0.890654 & S.D. depe & ndent var & 11442.86 \\
\hline S.E. of regression & 3783.867 & Akaike inf & fo criterion & 19.61733 \\
\hline Sum squared resid & $2.43 \mathrm{E}+08$ & Schwarz & criterion & 20.26494 \\
\hline Log likelihood & -290.0687 & Hannan-Q & uinn criter. & 19.82844 \\
\hline F-statistic & 19.79682 & Durbin-W & Vatson stat & 1.946862 \\
\hline Prob(F-statistic) & 0.000000 & & & \\
\hline
\end{tabular}

Table 4: Dependent Variable: D(GDP)

The other three equations in the ECM model system are:

$$
\begin{aligned}
& \Delta \operatorname{Re} m_{t}=\alpha_{20}+\alpha_{\operatorname{Re} m} \hat{e}_{t-1}+\sum_{i=1}^{m} \alpha_{21}(i) \Delta G D P_{t-i}+\sum_{i=1}^{m} \alpha_{22}(i) \Delta \operatorname{Re} m_{t-i}+\sum_{i=1}^{m} \alpha_{23}(i) \Delta F D I_{t-i}+ \\
& \sum_{i=1}^{m} \alpha_{24}(i) \Delta E x r_{t-i}+\varepsilon_{(\operatorname{Re} m) t} \ldots \ldots \ldots \ldots \ldots \ldots \ldots \ldots . . . \ldots \ldots \ldots \ldots \ldots
\end{aligned}
$$


$\Delta F D I_{t}=\alpha_{30}+\alpha_{F D I} \hat{e}_{t-1}+\sum_{i=1}^{m} \alpha_{31}(i) \Delta G D P_{t-i}+\sum_{i=1}^{m} \alpha_{32}(i) \Delta \operatorname{Re} m_{t-i}+\sum_{i=1}^{m} \alpha_{33}(i) \Delta F D I_{t-i}+$ $\sum_{i=1}^{m} \alpha_{34}(i) \Delta E x r_{t-i}+\varepsilon_{(F D I) t}$

$\Delta E x r_{t}=\alpha_{40}+\alpha_{E x r} \hat{e}_{t-1}+\sum_{i=1}^{m} \alpha_{41}(i) \Delta G D P_{t-i}+\sum_{i=1}^{m} \alpha_{42}(i) \operatorname{Re} m_{t-i}+\sum_{i=1}^{m} \alpha_{43}(i) \Delta F D I_{t-i}+$ $\sum_{i=1}^{m} \alpha_{44}(i) \Delta E x r_{t-i}+\varepsilon_{(E x r) t}$

$\hat{e}_{t-1}$ Is the error- correction term, $\alpha_{i}$ is the adjustment coefficient, and $\varepsilon_{i t}$ is the white-noise disturbance terms. If the variables have long-run relationship, the coefficient of $\alpha_{i}$ must be statistically significant. In table $4 \mathrm{C}(1)$ is the speed of adjustment towards long- run equilibrium but it must be significant, and the sign must be negative. From our results (Table-4) we can see that $C(1)$ is negative $(-0.0220220)$ but the $p$-value, $(0.8523)>0.05$. So, there is no long-run significant causality from the three independent variables (Rem, FDI, Exr). Meaning that Rem, FDI, and Exr have no statistically significant influence on the dependent variable GDP in the long-run. In other words, there is no statistically significant long-run causality running from Rem, FDI, and Exr to GDP. The results are given in the table 4 above.

\section{Wald test}

I used Wald Statistics to check the short run causality. Here, the null hypothesis Ho: $C(11)=C(12)=C(13)=0$ ( There is no short-run causality from export revenue to GDP). According to test results (Table-5), we can reject the Null hypothesis, because of our p-value $(0.000)<0.05$. So there is short-run causality from export revenue to GDP. The results of the test are given below:

Table 5: Wald Test

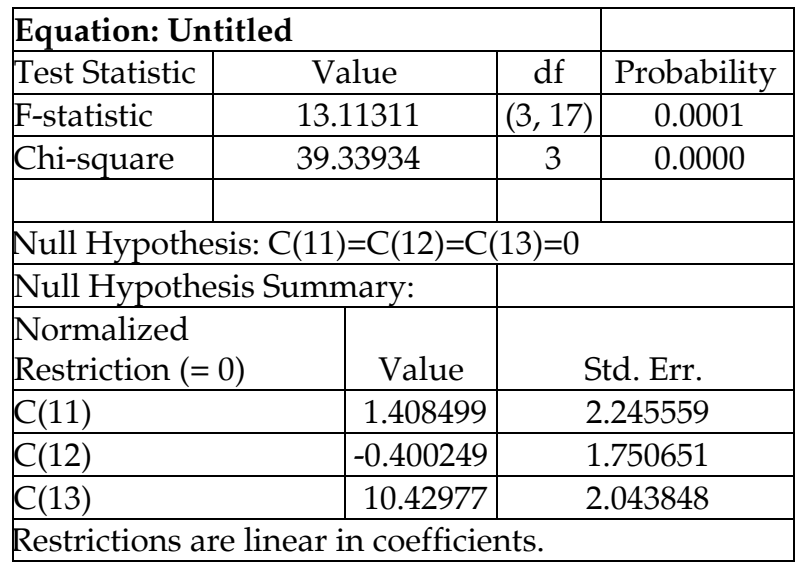

\section{Findings AND CONCLUSION}

The main objective of this study was to investigate the relationship between export revenue and GDP in Bangladesh. We know export revenue is an important factor for economic progress and GDP is a good criterion for measuring this progress. From Granger causality test I have seen, there is a bidirectional relationship between GDP and export revenue, which means that export revenue is the source of GDP in Bangladesh. In Johansen cointegration test there was a long-run relationship between GDP and export revenue. But in VECM there is no long-run significant relationship between the variables and the short-run relationship was checked by Wald test. It means that export should be limited. For attracting our goods and services to foreign countries, we should make the variation in goods and services and ensure the quality of goods and services. We should innovate new technology and create high skill labor force. Since Bangladesh exports a lot of garment products every year hence products quality must be outstanding. The government needs to support the garments industry by giving loan so that they can invest a lot.

\section{REFERENCES}

Ahmed, H.A. and Uddin, M.G.S. (2009), "Export, imports, remittance and growth in Bangladesh: An empirical Analysis", Trade and Development Review, Vol. 2 No. 2, pp.79-92.

Ahmed, Y. and Anoruo, E. (2000), "Openness and economic growth: Evidence from selected ASEAN countries", The Indian Economic Journal, Vol. 47 No. 3, pp. 110-117.

Akhter, M. (2015), "The impact of export and import on economic growth in Bangladesh", World Vision, Vol. 9 No. 1, pp. 66-81.

Arif, A., Ahmad, H. (2012), "Impact of trade openness on output growth: Co integration and error correction model approach", International Journal of Economics and Financial Issues, Vol. 2 No. 4, pp. 379-385.

Balaguer, J. and Cantavella-Jorda, M. (2010), "Examining the export-led growth hypothesis for Spain in the last century", Applied Economics Letters, Vol. 8 No. 10, pp. 681-685.

Bangladesh Bank (2015), Research Department, External Economics Division Vision.

Bangladesh Bureau of Statistics (2015), Statistics and Information Division (SID).

Bangladesh Economic Review (2015), Economics adviser's wing, Finance division, Ministry of finance.

Blomstrom, M. (1986), "Foreign investment and productivity efficiency: The case of Mexico", Journal of Industrial Economics, Vol.35 No.1, pp. 97-110.

Feder, G. (1982), "Export and economic growth", Journal of Development Economics, Vol.12 No.1-2, pp. 59-73.

Gujarati, D.N. (2005), Basic econometrics, Tata McGraw-Hill Publishing Company Limited, 7 West Patel Nagar, New Delhi 110008.

Hatemi-J, A. and Irandoust, M. (2000), “Export performance and economic growth causality: An empirical analysis", Atlantic Economic Journal, Vol. 28 No. 4, pp. 412-426.

Hur, J. and Park, C. (2012), “Do free trade agreements increase economic growth of the members countries", World Development, Elsevier, Vol. 40 No. 7, pp. 1283-1294.

Hussain, M.A. (2014), "Economic growth, exports and imports in Pakistan: Granger causality analysis", The Journal of Business in Developing Nations, Vol. 13, pp. 31-62.

International Monetary Fund, Balance of payment database, [supplemented by data from the United Nations conference on trade and development and official national sources] 
Ismail, A., Zaman, K., Atif, R.M., Jadoon, A. and Seemab, R. (2010), "The role of exports, inflation and investment on economic growth in Pakistan (1980-2009)", Int J Eco Res, Vol. 1 No. 1, pp. 1-9.

Javed, Z.H., Qauser, I., Mushtaq, A., Saif-ullah and Iqbal, A. (2012), "Effects of international trade on economic growth: The case study of Pakistan", International Journal of Academic Research in Progressive Education and Development, Vol. 1 No. 2, pp. 103-113.

Liargovas, P.G. and Konstantinos, S.S. (2012), "Foreign direct investment and trade openness: The case of developing economics", Social Indicator Research, Vol. 106 No. 2, pp. 323331.

Mishra, P.K. (2011), "The dynamics of relationship between exports and economic growth in India", International Journal of Economic Science and Applied Research, Vol.4 No.2, pp. 5370.

Moran, C. (1989), "Imports under a foreign exchange constraint", The World Bank Review, Vol.3 No.2, pp. 279-295.

Quddus, M.A. and Saeed, I. (2005), “An analysis of exports and growth in Pakistan", Pakistan Development Review, Vol. 44 No. 4, pp. 921-937.

Rai, K.S. and Jhala, P. (2015), "Impact of exports and imports on economic growth rate of India: An empirical enquiry", Pacific Business Review International, Vol. 8 No. 6, pp. 53-58.

Saaed, A.A.J. and Hussain, M. A. (2015), "Impact of export and imports on economic growth: Evidence from Tunisia",
Journal of Emerging Trends in Economics and Management Sciences, Vol. 6 No. 1, pp. 13-21.

Shaheen, S., Ali, M.M., Kauser, A. and Ahmed, F.B. (2013), "Impact of trade liberalization on economic growth in Pakistan", Interdisciplinary Journal of Contemporary Research in Business, Vol. 5 No. 5, pp. 228-240.

Siddiqui, A.H. and Iqbal, J. (2005), "Impact of trade openness on output growth for Pakistan: An empirical investigation", Munich Personal RePEc Archive, Vol. 1 No. 1.

Thirunavukkarasu, V. and Achchuthan, S. (2013), "Export, import and economic growth: Evidence from Sri Lanka", Journal of Economics and Sustainable Development, Vol. 4 No. 9, pp. 147-155.

Usman, M., Ashfaq, S. and Mushtaq, N. (2012), "Relationship of export and economic growth; An empirical study of Pakistan", Far East Journal of Psychology and Business, Vol. 6 No. 3, pp. 1-10.

World Bank National Accounts Data, and OECD National Accounts Data Files.

Yanikkaya, H. (2003), “Trade openness and economic growth: A cross-country empirical investigation", Journal of Development Economics, Elsevier, Vol. 72 No. 1, pp. 57-89.

Zaheer, R., Khattak, S.W., Ashar, H. and Khazaib. (2014), "Impact of exports import GDP growth rate, in Pakistan time series data from 2000-2010", International Journal of Research in Applied, Natural and Social Sciences, Vol. 2 No. 7, pp. 29-34.

$--0-$ 
Issue Link: $\underline{\text { https://doi.org/10.18034/abr.v8i1 }}$

Online Archive: $\underline{\text { https://abc.us.org/ojs/index.php/abr/issue/archive }}$ 